\title{
Soil physical attributes in forms of sowing the annual winter pasture and intervals between grazing ${ }^{1}$
}

\author{
Formas de semeadura de pastagem anual de inverno e intervalos entre pastejos \\ influenciando atributos físicos do solo
}

\author{
Milton da Veiga ${ }^{2 *}$, Alvadi Antonio Balbinot Junior ${ }^{3}$ e Daniela Aparecida de Oliveira ${ }^{4}$
}

\begin{abstract}
The sowing of winter pastures in areas used for summer grain production and their management under direct cattle grazing can cause changes in soil physical attributes, whose intensity depends on the degree of soil mobilization, grazing interval, stocking rate and weather. To study these aspects it was conducted over four years an experiment in a randomized block with split plots design and four replications. In the main plots were applied two forms of sowing the annual winter pasture (direct seeding and seeding + harrowing) and, in the subplots, four intervals between grazing ( 7,14 and 28 days and ungrazed). Undisturbed soil cores were sampled at the end of each grazing cycle, in the $0-0.05 \mathrm{~m}$ layer to determine the saturated hydraulic conductivity and aggregate stability and in the layers of 0-0.05, 0.05-0.10, 0.10-0.15 and 0.15-0.20 m depth to determine bulk density and classes of soil pores. The direct seeding of annual winter pasture increases hydraulic conductivity and reduces soil bulk density in relation to seeding + harrowing while dairy cows trampling increases soil density and reduces macroporosity in the most superficial soil layer. The variation in climatic conditions among grazing cycles affects the soil physical attributes more markedly than forms of sowing and intervals between grazing of the annual winter pasture.
\end{abstract}

Key words: Crop-livestock integration system. Bulk density. Porosity. Saturated hydraulic conductivity. Aggregate stability.

RESUMO - O cultivo de pastagens anuais de inverno em áreas de lavoura e o seu manejo sob pastejo direto de bovinos pode provocar alterações nos atributos físicos do solo, cuja intensidade depende do grau de mobilização do solo, do intervalo entre pastejos, da carga animal e das condições climáticas. Para estudar esses aspectos foi conduzido durante quatro anos um experimento em delineamento de blocos completos casualizados, com parcelas subdivididas e quatro repetições. Nas parcelas principais foram alocadas duas formas de implantação da pastagem de inverno (semeadura direta e semeadura + gradagem) e, nas subparcelas, quatro intervalos entre pastejos (sem pastejo e pastejo em intervalos de 7; 14 e 28 dias). Logo após a dessecação da pastagem, amostras de solo com estrutura preservada foram coletadas na camada de 0;00-0,05 m para determinação da condutividade hidráulica saturada e estabilidade de agregados e nas camadas de 0;00-0,05; 0,05-0,10;0.10-0,15 e 0,15-0,20 m de profundidade para determinar a densidade e as classes de poros do solo. A semeadura direta da pastagem anual de inverno aumentou a condutividade hidráulica saturada e reduziu a densidade do solo em relação à semeadura + gradagem, enquanto o pisoteio aumentou a densidade do solo e reduziu a macroporosidade na camada mais superficial do solo. A variação nas condições climáticas entre ciclos de pastejo afetou mais acentuadamente os atributos físicos do solo do que as formas de implantação da pastagem anual de inverno e os intervalos entre pastejos.

Palavras-chave: Sistema de integração lavoura-pecuária. Densidade do solo. Porosidade. Condutividade hidráulica saturada. Estabilidade dos agregados.

\footnotetext{
*Autor para correspondência

${ }^{1}$ Recebido para publicação em 31/01/2014; aprovado em 20/06/2014

Pesquisa financiada pela FAPESC/Jovem Doutor e CNPq/Repensa

${ }^{2}$ Estação Experimental de Campos Novos, Empresa de Pesquisa Agropecuária e Extensão Rural de Santa Catarina, Campos Novos-SC, Brasil, milveiga@epagri.sc.gov.br

${ }^{3}$ Centro Nacional de Pesquisa da Soja, Empresa Brasileira de Pesquisa Agropecuária, Londrina-PR, Brasil, alvadi.balbinot@embrapa.br

${ }^{4}$ Universidade do Oeste de Santa Catarina, Campos Novos-SC, Brasil, daniela.oliveira@unoesc.edu.br
} 


\section{INTRODUCTION}

The crop-livestock integration system (CLIS) is used in most small and medium farms of Southern Brazil, characterized mainly by the cultivation of annual pasture in the winter and the production of grain (maize, soybean or bean) or silage (maize or sorghum) in the summer. This system results in the intensification of land use for the production of annual crops and increased and diversified the income in properties, improving the ecological and economic system (BALBINOT JUNIOR et al., 2009a; BARTH NETO et al., 2014; SALTON et al., 2013). However, the CLIS requires proper management, since the use of crop area under grazing can cause surface soil compaction due to animal trampling and reduction of soil cover by straw before the sowing of summer crop in areas managed with no-till system (NICOLOSO; LANZANOVA; LOVATO, 2006; VEIGA et al., 2012).

The most common form of annual winter pasture sowing in Southern Brazil is the broadcast seeding and incorporation of seeds through harrowing. This practice results in tilling the topsoil, resulting in reduction of its resistance to compression and therefore increasing the potential for compaction by animal trampling (FLORES et al., 2007; VEIGA et al., 2007). For dairy cows, the winter pasture management in this region is usually rotational grazing, which is characterized by having high stocking rate in a short period, with an interval of return defined in terms of the pasture development or even at fixed intervals. In the last management, the pasture usually is subjected to intensive grazing, resulting in high trampling and compaction of the soil surface (BERTOL et al., 1998), which can be exacerbated when the grazing is carried out with favorable moisture to soil deformation (HÅKANSSON; VOORHEES, 1998).

Continued use of the CLIS can promote changes in soil physical attributes, such as increased bulk density and reduced macroporosity, both indicative of increased state of soil compaction (TREIN; COGO; LEVIEN, 1991). These changes, however, occur with greater intensity in the layer down to $0.1 \mathrm{~m}$ deep (FIGUEIREDO et al., 2009; LANZANOVA et al., 2007) and usually do not reach critical values that may limit the productivity of subsequent annual crops (MARCHÃO et al., 2007; SPERA et al., 2004). Some authors even found no significant differences in the attributes studied between systems with and without grazing (BALBINOR JUNIOR et al., 2009b; SILVA et al., 2000; SPERA et al., 2004), or even between grazing systems with different pasture heights, since pasture residue kept higher than 2 t ha $^{-1}$ (FLORES et al., 2007).

Therefore, there is a wide variation in results obtained by different authors, pointing to the need to perform this type of study in different soil and climatic conditions and for a long time. In this way, this study was performed to evaluate the effects of two forms of sowing and of four intervals between grazing of the winter pasture on soil physical attributes in the first four years of the experiment.

\section{MATERIAL AND METHODS}

The study was conducted during four years at the Epagri Experimental Station (Campos Novos-SC, Southern Brazil) at the geographical coordinates of $27^{\circ} 23^{\prime} 01^{\prime \prime} \mathrm{S}$ and $51^{\circ} 13$ ' $30^{\prime \prime} \mathrm{E}$ and altitude of $935 \mathrm{~m}$, in soil identified as Typic Hapludox (Nitossolo Vermelho Distrófico latossólico according to Brazilian classification) with very clayey texture (EMBRAPA, 2004). The treatments were allocated in a randomized complete block with split plot design and four replications. In the main plots, with $10 \times 20 \mathrm{~m}$, were used two forms of pasture sowing (direct seeding and seeding + harrowing) and in the subplots, with $5 \times 10 \mathrm{~m}$, were used four intervals between grazing (7, 14 and 28 days and ungrazed). The subplots were individualized with electric fence and dairy cows of Holstein and Jersey breeds were placed in the area surrounding the experiment every seven days, having free access to plots with grazing scheduled for the date. The animals were removed when the residual pasture had around $0.1 \mathrm{~m}$ high. The same intervals occurred between the last grazing and the soil sampling. Complete four grazing cycles were performed each year, totaling 14, 8 and 4 entries of the animals in the plots, respectively at intervals of 7,14 and 28 days between grazing.

The winter pasture consisted of a black oat (Avena strigosa Schreb, $100 \mathrm{~kg} \mathrm{ha}^{-1}$ ), annual ryegrass (Lolium multiflorum Lam, $20 \mathrm{~kg} \mathrm{ha}^{-1}$ ) and hairy vetch (Vicia vilosa Roth, $30 \mathrm{~kg} \mathrm{ha}^{-1}$ ) and, as summer crops, beans (Phaseolus vulgaris L.) and maize (Zea mays L.) for silage of whole plant, sowed in alternate years. The sowing of rye grass and hairy vetch was broadcasted and the oat was seeded with direct seeding machine in rows spaced $0.17 \mathrm{~m}$. In the seeding + harrowing treatment, the soil was harrowed until $0.05 \mathrm{~m}$ depth immediately after sowing the pasture. The sowing of maize and beans was held in rows spaced $0.5 \mathrm{~m}$ with a direct seeding machine equipped with cutting disc and a little chisel with depth of action until $0.12 \mathrm{~m}$, using seeds enough for an expected population of 60,000 and 240,000 plants $\mathrm{ha}^{-1}$, respectively for maize and bean. At sowing, were applied $300 \mathrm{~kg} \mathrm{ha}^{-1}$ of the 5-20-20 fertilizer $\left(\mathrm{N}-\mathrm{P}_{2} \mathrm{O}_{5}-\mathrm{K}_{2} \mathrm{O}\right)$ in the pasture and beans and the same amount of 8-20-20 fertilizer in maize. In coverage, were applied $300 \mathrm{~kg} \mathrm{ha}^{-1}$ of the $32-00-18$ fertilizer in maize and $150 \mathrm{~kg} \mathrm{ha}^{-1}$ of urea $\left(450 \mathrm{~g} \mathrm{~kg}^{-1}\right.$ of $\left.\mathrm{N}\right)$ in beans. 
The physical attributes was determined in soil samples collected at the end of each annual grazing cycle in volumetric rings with two dimensions: rings with $0.05 \mathrm{~m}$ high and $0.11 \mathrm{~m}$ diameter collected at two locations per plot in the layer of 0-0.05 $\mathrm{m}$ depth to determine the saturated hydraulic conductivity and aggregate stability; rings with $0.05 \mathrm{~m}$ high and $0.06 \mathrm{~m}$ diameter collected in a position per plot in the layers of 0-0.05, 0.05-0.10, 0.10-0.15 and 0.15-0.20 m depth to determine the bulk density an classes of soil pores. The soil sampling was performed in one quadrant of each subplot each year, in order to avoid subsequent sampling in the same place. The physical analyzes were performed using methods described in Veiga (2011), according to summarized description bellow.

The saturated hydraulic conductivity was determined at constant head permeameter of handmade confection. The samples were previously saturated by capillary and placed in the permeameter sets. A water column of $0.04 \mathrm{~m}$ was applied above the sample surface and allowed percolation for a period of two hours prior to collection of water to determine the volume percolated through sample in an interval of 10 minutes. The calculation of the saturated hydraulic conductivity was performed using the formula:

$$
K \theta_{s}\left(m h^{-1}\right)=[(V x L) /(A x \Delta t \times h)] / 100
$$

where: $V$ represents the volume of water $\left(\mathrm{cm}^{3}\right)$ sampled at a time interval $\Delta t(\mathrm{~h}) ; A$ the surface area of the sample $\left(\mathrm{cm}^{2}\right) ; L$ the sample height $(\mathrm{cm})$; and $h$ the water column above the surface of the sample $(\mathrm{cm})$. The number 100 is used to express the results in $m h^{-1}$.

In the same samples were determined the geometric mean diameter of air dried (GMDad) and water stable (GMDws) of soil aggregates and calculated the index of aggregate stability (IAS = GMDws/GMDad).

To calculate the soil bulk density and classes of soil pores was determined, sequentially, the mass of the sample after saturation by capillary, after application of tensions of $6 \mathrm{kPa}$ (sand box) and $600 \mathrm{kPa}$ (Richards apparatus) and after drying the sample at $105^{\circ} \mathrm{C}$ to constant mass. The bulk density $\left(\mathrm{Mg} \mathrm{m}^{-3}\right)$ corresponds to the ratio between the mass of dry soil and the internal volume of the volumetric ring. The total volume of pores, macropores, mesopores and micropores $\left(\mathrm{m}^{3} \mathrm{~m}^{-3}\right)$ correspond, respectively, to the water held in the soil after saturation, between saturation and $6 \mathrm{kPa}$ tension (pores with $\varnothing>50 \mu \mathrm{m}$ ), between the tensions of 6 and $600 \mathrm{kPa}$ (pores with $\varnothing=50-0.5 \mu \mathrm{m}$ ) and in the tension of $600 \mathrm{kPa}$ (pores with $\varnothing<0.5 \mu \mathrm{m}$ ), all calculated relative to the internal volume of the respective volumetric ring.
The resistance to penetration was determined at the time of soil sampling in the fourth year of experimentation, using a penetrometer Falker model PLG 5300, equipped with pin penetration of $0.6 \mathrm{~m}$ height and conical tip with angle of $30^{\circ}$, penetration in constant rate of $0,035 \mathrm{~m} \mathrm{~s}^{-1}$, recording the values at intervals of $0.01 \mathrm{~m}$ down to $0.3 \mathrm{~m}$ depth. This determination was performed two days after a rainfall event of sufficient amount to soil moisture reach the field capacity in the layer evaluated.

The residual of pasture biomass was determined at two positions per plot at the end of each grazing cycle, sampling the reminiscent pasture shoot in $0.25 \mathrm{~m}^{2}$ and oven dried with forced air circulation at $60{ }^{\circ} \mathrm{C}$ to constant mass, with values presented in $\mathrm{kg} \mathrm{ha}^{-1}$. Rainfall was measured at a Meteorological Station located approximately $0.5 \mathrm{~km}$ from the experiment.

The analysis of variance was performed individually for each soil layer and, when verified significance by $\mathrm{F}$ tests, the means were compared by Tukey test $(\mathrm{P}<0.05)$. Due to the lack of homogeneity of the variances, the values of saturated hydraulic conductivity were adjusted by the equation $x^{\prime}=\sqrt{ }(1+x)$. The comparison between means of the attributes related to the aggregate stability (MGDws and IAE) was performed considering the covariance between the values of these attributes and the moisture of the soil samples at the completion of the aggregate stability test (antecedent moisture), as recommended in Veiga, Reinert e Reichert (2009). Because have been found homogeneity of the residual variance, there was performed a joint analysis after analyzing the data for each year of the experiment. We considered the existence of homogeneity when there was a ratio lesser than seven between the highest and lowest residual mean square (PIMENTEL GOMES, 1985).

\section{RESULTS AND DISCUSSION}

The form of sowing of the annual winter pasture did not affect the saturated hydraulic conductivity (SHC) in the 0.00-0.05 m layer and the SHC decreased with the reduction of the interval between grazing (Table 1), indicating that the cattle trampling reduces the amount and continuity of pores responsible for the rapid flow of water and air through the soil, as also pointed out by Miguel et al. (2009). The SHC also varied significantly between the years studied, with higher value in 2010, when there was the least amount of rainfall in the period in which the pasture was subjected to grazing, especially in the last month of that period (Table 2). 
Table 1 - Physical attributes of the soil at 0.00-0.05 m layer, determined in four years of using of two forms of sowing and four intervals between grazing of the annual winter pasture

\begin{tabular}{|c|c|c|c|c|}
\hline \multirow{3}{*}{ Treatments } & \multicolumn{4}{|c|}{----------------------------------------------Physical attributes---------------------------------------------- } \\
\hline & $\mathrm{SHC}^{1}$ & GMDad & GMDws $^{2}$ & \multirow{2}{*}{ IAS $^{2}$} \\
\hline & $\mathrm{mm} \mathrm{h}^{-1}$ & \multicolumn{2}{|c|}{--------------------------- $\mathrm{mm}$------------------------ } & \\
\hline \multicolumn{5}{|c|}{ Forms of sowing } \\
\hline DS & $249^{N S}$ & $1.94 \mathrm{a}$ & $1.14^{\mathrm{NS}}$ & $0.605^{\mathrm{NS}}$ \\
\hline $\mathrm{S}+\mathrm{H}$ & 202 & $1.85 \mathrm{~b}$ & 1.14 & 0.623 \\
\hline $\mathrm{CV}(\%)$ & 56.0 & 4.4 & 22.8 & 17.8 \\
\hline \multicolumn{5}{|c|}{ Interval between grazing } \\
\hline $7 \mathrm{D}$ & $167 \mathrm{~b}$ & $1.90^{\mathrm{NS}}$ & $1.07 \mathrm{~b}$ & $0.579 \mathrm{~b}$ \\
\hline $14 \mathrm{D}$ & $218 \mathrm{ab}$ & 1.89 & $1.12 \mathrm{ab}$ & $0.606 \mathrm{ab}$ \\
\hline $28 \mathrm{D}$ & $209 \mathrm{~b}$ & 1.90 & $1.18 \mathrm{a}$ & $0.638 \mathrm{a}$ \\
\hline UG & $309 \mathrm{a}$ & 1.90 & $1.18 \mathrm{a}$ & $0.632 \mathrm{a}$ \\
\hline $\mathrm{CV}(\%)$ & 31.3 & 13.9 & 22.8 & 17.8 \\
\hline \multicolumn{5}{|c|}{ Years } \\
\hline 2009 & $172 \mathrm{~b}$ & $1.88 \mathrm{~b}$ & $1.04 \mathrm{c}$ & $0.566 \mathrm{c}$ \\
\hline 2010 & $348 \mathrm{a}$ & $1.51 \mathrm{~d}$ & $0.91 \mathrm{~d}$ & $0.612 b c$ \\
\hline 2011 & $224 \mathrm{~b}$ & $2.32 \mathrm{a}$ & $1.43 \mathrm{a}$ & $0.617 \mathrm{~b}$ \\
\hline 2012 & $221 \mathrm{~b}$ & $1.69 \mathrm{c}$ & $1.16 \mathrm{~b}$ & $0.660 \mathrm{a}$ \\
\hline $\mathrm{CV}(\%)$ & 46.3 & 11.5 & 22.8 & 17.8 \\
\hline
\end{tabular}

SHC: saturated hydraulic conductivity; GMDad: geometric mean diameter of air-dried aggregates; GMDws: geometric mean diameter of water-stable aggregates; IAS: index of aggregate stability (GMDws/GMDad); DS: direct seeding; S+H: seeding + harrowing; 7D, 14D and 28D: grazing in intervals of 7, 14 and 28 days, respectively; UG: ungrazed; Means followed by different letters within each source of variation in the column differ significantly (Tukey test, $\mathrm{P}<0.05)$; NS: no significant differences; 1 : Comparison of means performed with the data transformed by $\sqrt{ }(1+\mathrm{x})$, with presentation of the original data; 2: Comparison of means performed by correcting the effect of covariance associated with antecedent moisture of the samples

Table 2 - Total monthly precipitation during the period of grazing in four years of experimentation

\begin{tabular}{|c|c|c|c|c|}
\hline \multirow[b]{2}{*}{ Month } & \multicolumn{4}{|c|}{ 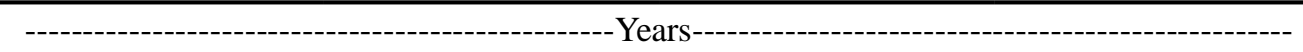 } \\
\hline & 2009 & 2010 & 2011 & 2012 \\
\hline June & 60.4 & 89.1 & 182.7 & 149.8 \\
\hline July & 282.8 & 168.1 & 294.0 & 210.4 \\
\hline August & 236.6 & 84.3 & 375.0 & 0.4 \\
\hline September & 497.1 & 132.4 & 320.8 & 95.8 \\
\hline October & 179.9 & 155.8 & 234.7 & 208.8 \\
\hline Total & 1.256 .8 & 629.7 & 1.407 .2 & 665.2 \\
\hline
\end{tabular}

The sowing of pasture by direct seeding increased the geometric mean diameter of air-dried (GMDad) aggregates in relation to seeding + harrowing, but did not affect the geometric mean diameter of water-stable aggregates (GMDws) and the index of aggregate stability (IAS) in layer of 0-0.05 $\mathrm{m}$ depth
(Table 1). The greater GMDad found in direct seeding can be explained by the higher degree of surface soil consolidation because of its less soil mobilization, as also observed by Veiga et al. (2007) when compared no-till with tilled treatments, which is related to the positive correlation between bulk density and GMDad. 
On the other hand, the intensity of animal trampling did not affect the GMDad, but the attributes related to aggregate stability (GMDws and IAS) increased with increasing grazing interval, with the highest value being observed in the ungrazed treatment. This increase may be related to the stabilization of soil aggregates promoted by roots, which have a transitory effect on the stability of the soil aggregates (TISDALL; OADES, 1982), associated with the fact that pastures are more efficient than annual crops in this process (BALBINOT JUNIOR et al., 2009b; SALTON et al., 2013).

It was also observed the increase in the IAS over the years of experimentation, probably due to the contribution of root and shoot biomass of pasture added to the soil year by year (Table 3), because in addition to the temporary effect of roots, organic agents produced by the decomposition of organic matter may have transient (polysaccharides derived from the decomposition of organic matter and root exudates) or durable effect (resistant aromatic compounds adsorbed strongly associated with polyvalent metal cations and polymers) on the formation and stabilization of soil aggregates (TISDALL; OADES, 1982). SHC, GMDad, GMDws and IAE attributes in the 0.00-0.05 m layer were not influenced by interactions between the experimental factors.

The forms of sowing the annual winter pasture and the interaction between the experimental factors did not affect the bulk density and porosity of the soil sampled in the four layers (Tables 4 and 5). On the other hand, the intervals between grazing affected the bulk density and macroporosity only in the most superficial layer, corroborating results obtained by Figueiredo et al. (2009) and Lanzanova et al. (2007). It was observed a lower bulk density and increased volume of macropores in the layer of 0.00-0.05 $\mathrm{m}$ depth in the ungrazing treatment, indicating that the dairy cows trampling promoted change in mass-volume relations only in the topsoil layer. It is important to consider that compacted layer of only $0.05 \mathrm{~m}$ depth is easily broken by the little chisel of the direct seeding planter at the time of sowing the summer crops in succession to annual winter pasture. Moreover, it was found larger effect of years on the soil bulk density and porosity (Tables 4 and 5), probably due to the use of different summer crops and, especially, because different water regimes in the winter period. These results indicate that climatic conditions during the grazing period are more important than the frequency of trampling in determining the degree of soil compaction.

The differences between years were observed in most of the attributes and layers, with no relation with the time of treatment application. Higher bulk density was observed in the two surface layers in 2011 and 2009, which were rainier during the grazing period than the others years (Table 2), a condition that favored the surface compaction by trampling. This is because soil compaction caused by applying mechanical pressure is dependent on the width of the applied pressure and strongly influenced by the water content of the soil, with the greatest magnitude under intermediate soil moisture (HAKANSSON; VOORHEES, 1998). In this context, strategies of cattle management to reduce the permanence of animals at field when the soil has more favorable conditions to deformation is relevant to minimize the effect of trampling on soil compaction. The reduction in bulk density between years when the grazing period had higher (2009 and 2011) and lower rainfall (2010 and 2012) can be explained by the rearrangement of particles promoted by cycles of soil expansion (wetting) and contraction (drying) during the cycle of the summer crop, which occurs in greater magnitude in the topsoil

Table 3 - Shoot dry mass remaining at the desiccation of annual winter pasture in four years of using four intervals between grazing (means across two forms of sowing the annual winter pasture)

\begin{tabular}{|c|c|c|c|c|c|}
\hline \multirow{3}{*}{ Interval between grazing } & \multicolumn{5}{|c|}{ 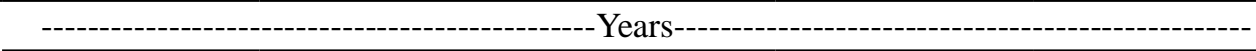 } \\
\hline & 2009 & 2010 & 2011 & 2012 & Average \\
\hline & \multicolumn{4}{|c|}{ 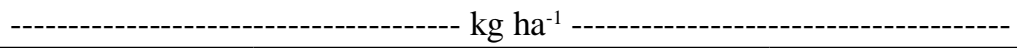 } & $\mathrm{kg} \mathrm{ha}^{-1}$ year $^{-1}$ \\
\hline $7 \mathrm{D}$ & $321 \mathrm{c}$ & $560 \mathrm{c}$ & $849 \mathrm{~d}$ & $1.667 \mathrm{c}$ & 849 \\
\hline $14 \mathrm{D}$ & $769 \mathrm{bc}$ & $1.447 \mathrm{c}$ & $1.506 \mathrm{c}$ & $2.302 \mathrm{c}$ & 1.506 \\
\hline $28 \mathrm{D}$ & $1.895 \mathrm{~b}$ & $3.504 b$ & $2.941 \mathrm{~b}$ & $3.426 \mathrm{~b}$ & 2.942 \\
\hline UG & $5.547 \mathrm{a}$ & $6.233 \mathrm{a}$ & $5.656 \mathrm{a}$ & $5.189 \mathrm{a}$ & 5.652 \\
\hline $\mathrm{CV}(\%)$ & 50.2 & 34.9 & 15.8 & 28.8 & \\
\hline
\end{tabular}

7D, 14D and 28D: intervals of 7, 14 and 28 days between grazing, respectively; UG: ungrazed 
Table 4 - Soil bulk density and porosity in four layers of a Hapludox in four years of evaluation of two forms of sowing and four intervals between grazing of annual winter pasture

\begin{tabular}{|c|c|c|c|c|}
\hline \multirow{2}{*}{ Attributes/Treataments } & \multicolumn{4}{|c|}{ 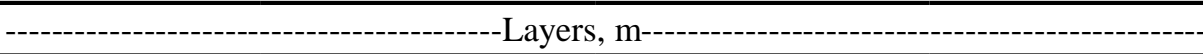 } \\
\hline & $0-0.05$ & $0.05-0.10$ & $0.10-0.15$ & $0.15-0.20$ \\
\hline \multicolumn{5}{|c|}{ Soil bulk density, $\mathrm{Mg} \mathrm{m}^{-3}$} \\
\hline \multicolumn{5}{|c|}{ Forms of sowing } \\
\hline DS & $1.13^{\mathrm{NS}}$ & $1.22^{\mathrm{NS}}$ & $1.26^{\mathrm{NS}}$ & $1.26^{\mathrm{NS}}$ \\
\hline $\mathrm{S}+\mathrm{H}$ & 1.13 & 1.23 & 1.25 & 1.24 \\
\hline $\mathrm{CV}(\%)$ & 10.4 & 7.4 & 1.8 & 6.0 \\
\hline \multicolumn{5}{|c|}{ Interval between grazing } \\
\hline $7 \mathrm{D}$ & $1.18 \mathrm{a}$ & $1.24^{\mathrm{NS}}$ & $1.26^{\mathrm{NS}}$ & $1.25^{\mathrm{NS}}$ \\
\hline $14 \mathrm{D}$ & $1.14 \mathrm{ab}$ & 1.20 & 1.26 & 1.25 \\
\hline $28 \mathrm{D}$ & $1.14 \mathrm{ab}$ & 1.23 & 1.26 & 1.26 \\
\hline $\mathrm{UG}$ & $1.07 \mathrm{~b}$ & 1.23 & 1.26 & 1.25 \\
\hline $\mathrm{CV}(\%)$ & 9.1 & 6.5 & 4.6 & 4.5 \\
\hline \multicolumn{5}{|c|}{ Years } \\
\hline 2009 & $1.14 \mathrm{ab}$ & $1.22 \mathrm{ab}$ & $1.26^{\mathrm{NS}}$ & $1.20 \mathrm{~b}$ \\
\hline 2010 & $1.11 \mathrm{~b}$ & $1.20 \mathrm{~b}$ & 1.26 & $1.25 \mathrm{a}$ \\
\hline 2011 & $1.18 \mathrm{a}$ & $1.27 \mathrm{a}$ & 1.25 & $1.26 \mathrm{a}$ \\
\hline 2012 & $1.09 \mathrm{~b}$ & $1.21 \mathrm{~b}$ & 1.26 & $1.27 \mathrm{a}$ \\
\hline $\mathrm{CV}(\%)$ & 7.8 & 6.5 & 5.1 & 5.7 \\
\hline \multicolumn{5}{|c|}{ Total porosity, $\mathrm{m}^{3} \mathrm{~m}^{-3}$} \\
\hline \multicolumn{5}{|c|}{ Forms of sowing } \\
\hline DS & $0.582^{\mathrm{NS}}$ & $0.575^{\mathrm{NS}}$ & $0.548^{\mathrm{NS}}$ & $0.557^{\mathrm{NS}}$ \\
\hline $\mathrm{S}+\mathrm{H}$ & 0.574 & 0.558 & 0.551 & 0.543 \\
\hline $\mathrm{CV}(\%)$ & 10.8 & 10.7 & 12.3 & 7.9 \\
\hline \multicolumn{5}{|c|}{ Interval between grazing } \\
\hline $7 \mathrm{D}$ & $0.572^{\mathrm{NS}}$ & $0.570^{\mathrm{NS}}$ & $0.553^{\mathrm{NS}}$ & $0.555^{\mathrm{NS}}$ \\
\hline $14 \mathrm{D}$ & 0.575 & 0.564 & 0.550 & 0.542 \\
\hline $28 \mathrm{D}$ & 0.585 & 0.561 & 0.541 & 0.548 \\
\hline $\mathrm{UG}$ & 0.579 & 0.571 & 0.555 & 0.555 \\
\hline $\mathrm{CV}(\%)$ & 7.9 & 8.0 & 6.6 & 6.3 \\
\hline \multicolumn{5}{|c|}{ Years } \\
\hline 2009 & $0.562^{\mathrm{NS}}$ & $0.555 \mathrm{~b}$ & $0.551^{\mathrm{NS}}$ & $0.560 \mathrm{a}$ \\
\hline 2010 & 0.584 & $0.590 \mathrm{a}$ & 0.553 & $0.573 \mathrm{a}$ \\
\hline 2011 & 0.579 & $0.574 \mathrm{ab}$ & 0.550 & $0.550 \mathrm{a}$ \\
\hline 2012 & 0.587 & $0.547 \mathrm{~b}$ & 0.546 & $0.517 \mathrm{~b}$ \\
\hline $\mathrm{CV}(\%)$ & 7.8 & 9.0 & 5.8 & 8.1 \\
\hline
\end{tabular}

DS: direct seeding; S+H: seeding + harrowing; 7D, 14D and 28D: grazing in intervals of 7, 14 and 28 days, respectively; UG: ungrazed. Means followed by different letters within each attribute and source of variation differ significantly (Tukey test, $\mathrm{P}<0.05$ ); NS: no significant differences 
Table 5 - Classes of soil pores in four layers of a Hapludox in four years of two forms of sowing and four intervals between grazing of the annual winter pasture

\begin{tabular}{|c|c|c|c|c|}
\hline \multirow{2}{*}{ Attributes/ Treataments } & & & & \\
\hline & $0-0.05$ & $0.05-0.10$ & $0.10-0.15$ & $0.15-0.20$ \\
\hline \multicolumn{5}{|c|}{ Macropores $(\varnothing>50 \mu \mathrm{m}), \mathrm{m}^{3} \mathrm{~m}^{-3}$} \\
\hline \multicolumn{5}{|c|}{ Forms of sowing } \\
\hline $\mathrm{DS}$ & $0.154^{\mathrm{NS}}$ & $0.147^{\mathrm{NS}}$ & $0.134^{\mathrm{NS}}$ & $0.124^{\mathrm{NS}}$ \\
\hline $\mathrm{S}+\mathrm{H}$ & 0.158 & 0.140 & 0.130 & 0.123 \\
\hline $\mathrm{CV}(\%)$ & 32.8 & 37.9 & 39.1 & 19.7 \\
\hline \multicolumn{5}{|c|}{ Intervals between grazing } \\
\hline $7 \mathrm{D}$ & $0.149 \mathrm{ab}$ & $0.139^{\mathrm{NS}}$ & $0.130^{\mathrm{NS}}$ & $0.122^{\mathrm{NS}}$ \\
\hline $14 \mathrm{D}$ & $0.157 \mathrm{ab}$ & 0.150 & 0.134 & 0.122 \\
\hline $28 \mathrm{D}$ & $0.146 \mathrm{~b}$ & 0.143 & 0.128 & 0.122 \\
\hline UG & $0.171 \mathrm{a}$ & 0.143 & 0.135 & 0.127 \\
\hline $\mathrm{CV}(\%)$ & 20.7 & 15.8 & 12.2 & 12.8 \\
\hline \multicolumn{5}{|c|}{ Years } \\
\hline 2009 & $0.118 \mathrm{~b}$ & $0.125 \mathrm{c}$ & $0.107 \mathrm{~b}$ & $0.098 \mathrm{~b}$ \\
\hline 2010 & $0.187 \mathrm{a}$ & $0.169 \mathrm{a}$ & $0.153 \mathrm{a}$ & $0.135 \mathrm{a}$ \\
\hline 2011 & $0.134 \mathrm{~b}$ & $0.132 \mathrm{bc}$ & $0.134 \mathrm{a}$ & $0.131 \mathrm{a}$ \\
\hline 2012 & $0.184 \mathrm{a}$ & $0.149 \mathrm{~b}$ & $0.132 \mathrm{a}$ & $0.129 \mathrm{a}$ \\
\hline $\mathrm{CV}(\%)$ & 24.0 & 19.4 & 25.5 & 22.2 \\
\hline \multicolumn{5}{|c|}{ Mesopores $(\varnothing=50-0.05 \mu \mathrm{m}), \mathrm{m}^{3} \mathrm{~m}^{-3}$} \\
\hline \multicolumn{5}{|c|}{ Forms of sowing } \\
\hline DS & $0.068^{\mathrm{NS}}$ & $0.060^{\mathrm{NS}}$ & $0.054^{\mathrm{NS}}$ & $0.052^{\mathrm{NS}}$ \\
\hline $\mathrm{S}+\mathrm{H}$ & 0.073 & 0.059 & 0.057 & 0.055 \\
\hline $\mathrm{CV}(\%)$ & 31.2 & 48.3 & 32.8 & 28.3 \\
\hline \multicolumn{5}{|c|}{ Intervals between grazing } \\
\hline $7 \mathrm{D}$ & $0.067^{\mathrm{NS}}$ & $0.057^{\mathrm{NS}}$ & $0.053^{\mathrm{NS}}$ & $0.053^{\mathrm{NS}}$ \\
\hline $14 \mathrm{D}$ & 0.074 & 0.058 & 0.055 & 0.052 \\
\hline $28 \mathrm{D}$ & 0.073 & 0.066 & 0.059 & 0.055 \\
\hline UG & 0.067 & 0.057 & 0.056 & 0.054 \\
\hline $\mathrm{CV}(\%)$ & 23.5 & 52.1 & 27.8 & 26.3 \\
\hline \multicolumn{5}{|c|}{ Years } \\
\hline 2009 & $0.084 \mathrm{a}$ & $0.068 \mathrm{a}$ & $0.066 \mathrm{ab}$ & $0.064 \mathrm{a}$ \\
\hline 2010 & $0.069 \mathrm{~b}$ & $0.062 \mathrm{a}$ & $0.056 \mathrm{~b}$ & $0.049 \mathrm{~b}$ \\
\hline 2011 & $0.087 \mathrm{a}$ & $0.074 \mathrm{a}$ & $0.068 \mathrm{a}$ & $0.069 \mathrm{a}$ \\
\hline 2012 & $0.041 \mathrm{c}$ & $0.034 \mathrm{~b}$ & $0.033 \mathrm{c}$ & $0.032 \mathrm{c}$ \\
\hline $\mathrm{CV}(\%)$ & 21.8 & 41.7 & 26.6 & 24.1 \\
\hline
\end{tabular}


Table 5 Continued

\begin{tabular}{|c|c|c|c|c|}
\hline \multicolumn{5}{|c|}{ Micropores $(\varnothing<0.05 \mu \mathrm{m}), \mathrm{m}^{3} \mathrm{~m}^{-3}$} \\
\hline \multicolumn{5}{|c|}{ Forms of sowing } \\
\hline $\mathrm{DS}$ & $0.360^{\mathrm{NS}}$ & $0.368^{\mathrm{NS}}$ & $0.360^{\mathrm{NS}}$ & $0.381^{\mathrm{NS}}$ \\
\hline $\mathrm{S}+\mathrm{H}$ & 0.344 & 0.359 & 0.365 & 0.365 \\
\hline $\mathrm{CV}(\%)$ & 24.3 & 10.2 & 9.7 & 17.2 \\
\hline \multicolumn{5}{|c|}{ Intervals between grazing } \\
\hline $7 \mathrm{D}$ & $0.356^{\mathrm{NS}}$ & $0.374^{\mathrm{NS}}$ & $0.371^{\mathrm{NS}}$ & $0.381^{\mathrm{NS}}$ \\
\hline $14 \mathrm{D}$ & 0.344 & 0.357 & 0.361 & 0.368 \\
\hline 28D & 0.366 & 0.351 & 0.355 & 0.370 \\
\hline $\mathrm{UG}$ & 0.341 & 0.372 & 0.364 & 0.374 \\
\hline $\mathrm{CV}(\%)$ & 16.1 & 13.0 & 10.8 & 9.5 \\
\hline \multicolumn{5}{|c|}{ Years } \\
\hline 2009 & $0.360^{\mathrm{NS}}$ & $0.362^{\mathrm{NS}}$ & $0.378 \mathrm{a}$ & $0.398 \mathrm{a}$ \\
\hline 2010 & 0.328 & 0.359 & $0.344 \mathrm{~b}$ & $0.389 \mathrm{a}$ \\
\hline 2011 & 0.358 & 0.368 & $0.348 \mathrm{~b}$ & $0.350 \mathrm{~b}$ \\
\hline 2012 & 0.361 & 0.364 & $0.380 \mathrm{a}$ & $0.356 \mathrm{~b}$ \\
\hline $\mathrm{CV}(\%)$ & 14.3 & 10.9 & 7.7 & 11.9 \\
\hline
\end{tabular}

DS: direct seeding; S+H: seeding + harrowing; 7D, 14D and 28D: grazing in intervals of 7, 14 and 28 days, respectively; UG: ungrazed. Means followed by different letters within each attribute and source of variation differ significantly (Tukey test, $\mathrm{P}<0.05$ ); ${ }^{\mathrm{N} S}$ : no significant differences

(AHUJA et al., 1998; VEIGA et al., 2008), without recompaction of the soil during the subsequent grazing cycle with lower volume of rainfall.

The increasing in bulk density was reflected in lower macroporosity and higher volume of mesopores, with little effect on total porosity. Total porosity was higher in 2010 in the layers of $0.05-0.10$ and 0.15 $0.20 \mathrm{~m}$ depth. In that same year, the macroporosity was higher at $0-0.05 \mathrm{~m}$ depth, demonstrating that the conditions of soil moisture during the grazing cycle were less favorable to compaction. The volume of micropores was changed only in the layers located below $0.10 \mathrm{~m}$ depth, without a defined trend between years. Thus, it can be inferred that compaction promoted by animal trampling is confined to the topsoil, as also observed by other authors (FIGUEIREDO et al., 2009; LANZANOVA et al., 2007), but is not persistent, being dissipated by cycles of soil wetting and drying that occur during the summer crop cycle, when the soil is not subject to animal trampling.

The resistance to penetration was not affected by forms of sowing the annual winter pasture (Figure 1) and the interaction between the experimental factors. On the other hand, there was greater resistance to penetration around $0.05 \mathrm{~m}$ depth in treatments with shorter interval between grazing, agreeing with the data of bulk density (Table 3 ). In southern Brazil is very common of using periods between grazing shorter than 15 days in rotational grazing of the annual winter pasture that, associated with high stocking rate, can cause soil compaction and damage to root grown of crops cultivated in succession in the integrated crop-livestock system, especially in the earlier stages of crop growing.

Other important finding is that, in treatments with grazing, the resistance to penetration was greater than 2.0 MPa in the 0.10-0.20 m layer (Figure 1), considered restrictive to root growth of most agricultural crops (REICHERT; SUZUKI; REINERT, 2007). However, in the ungrazed treatment the resistance to penetration in this layer has not reached $2.0 \mathrm{MPa}$. In a study with different stocking rate in annual winter pasture, Debiasi e Franchini (2012) found that cattle trampling increased resistance to penetration at values greater than $2.0 \mathrm{MPa}$ down to $0.30 \mathrm{~m}$ depth, due to the high stocking rate and favorable level of soil moisture to soil compaction. 
Figure 1 - Profiles of soil penetration resistance at the end of the grazing period in the fourth year of experimentation in two forms of sowing (A) and four intervals between grazing (B) of the winter pasture in a Hapludox. DS: direct seeding, S + H: seeding + harrowing; LSD: least significant difference (solid line = significant at 5\% level, dotted line = no significant difference); 7D, 14D and 28D: grazing in intervals of 7, 14 and 28 days, respectively; UG: ungrazed

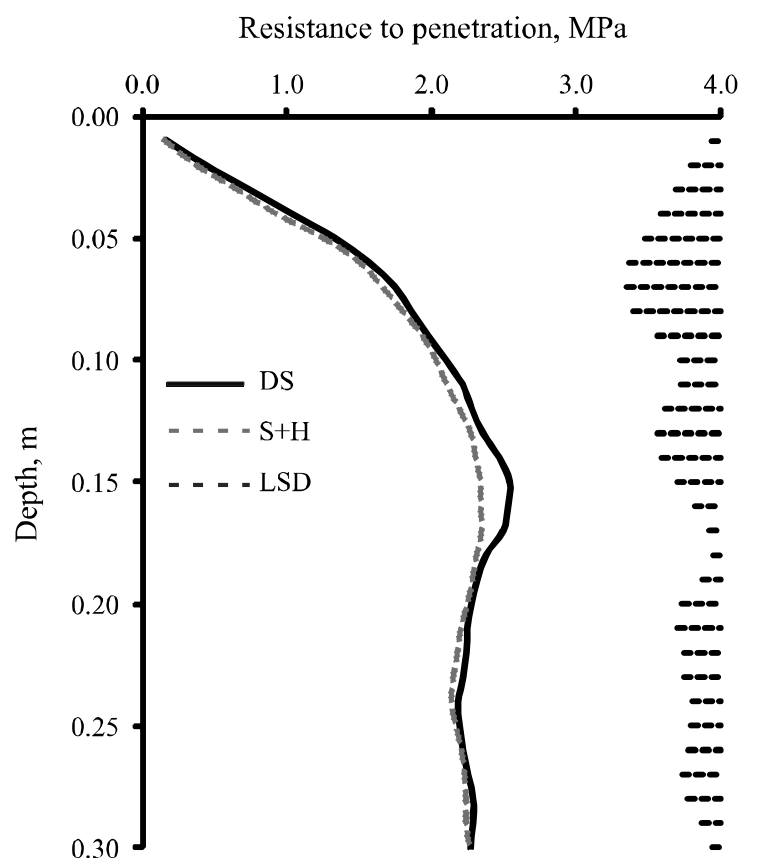

\section{CONCLUSIONS}

1. Direct seeding and seeding plus harrowing of the annual winter pasture have the same effect on physical attributes related to soil compaction;

2. Dairy cows trampling increases soil bulk density and reduce macroporosity only in the topsoil layer (0-0.05 m depth) and surface compaction increases with the reduction of the interval between grazing;

3. The variation in climatic conditions among grazing cycles affects the soil physical attributes more markedly than forms of sowing and intervals between grazing of the annual winter pasture.

\section{REFERENCES}

AHUJA, L. R. et al. Changes in soil water retention curves due to tillage and natural reconsolidation. Soil Science Society of America Journal, v. 62, n. 5, p. 1228-1233, 1998.

BALBINOT JUNIOR, A. A. et al. Integração lavourapecuária: intensificação de uso de áreas agrícolas. Ciência Rural, v. 99, n. 6, p. 1925-1933, 2009a.

BALBINOT JUNIOR, A. A. et al. Propriedades físicas em Cambissolo Háplico manejado sob o sistema de integração

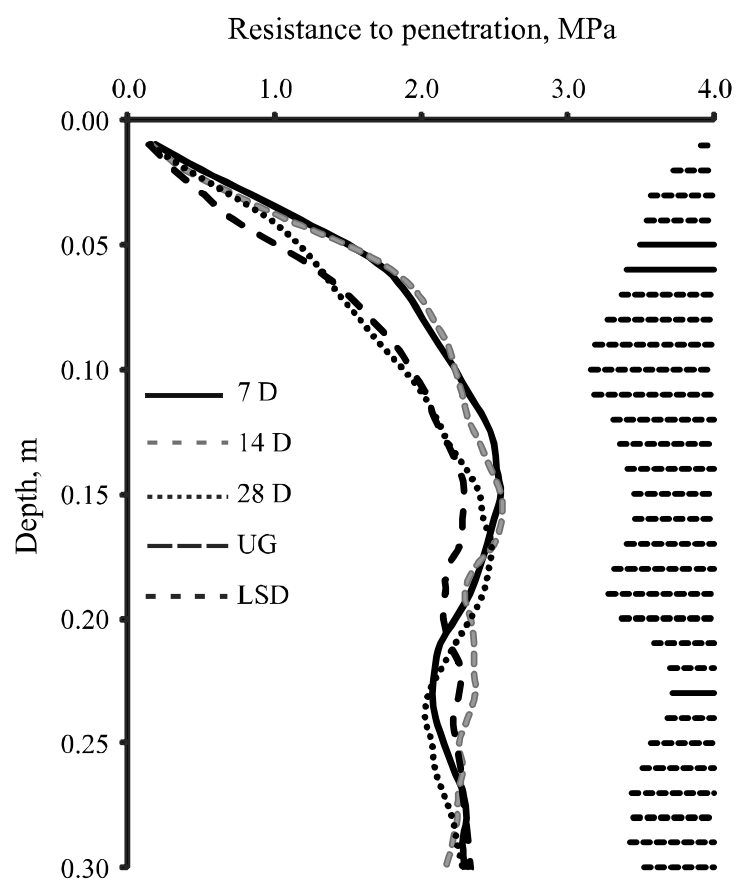

lavoura-pecuária. Revista de Ciências Agroveterinárias, v. 8, n. 1, p. 25-34, 2009b.

BARTH NETO, A. et al. Italian ryegrass establishment by self-seeding in integrated crop-livestock systems: effects of grazing management and crop rotation strategies. European Journal of Agronomy, v.53, n. 1, p. 67-73, 2014.

BERTOL, I. et al. Propriedades físicas do solo relacionadas a diferentes níveis de oferta de forragem numa pastagem natural. Pesquisa Agropecuária Brasileira, v. 33, n. 5, p. 779786, 1998.

DEBIASI, H.; FRANCHINI, J. C. Atributos físicos do solo e produtividade da soja em sistemas de integração lavourapecuária com braquiária e soja. Ciência Rural, v. 42, n. 7, p. 1180-1186, 2012.

EMPRESA BRASILEIRA DE PESQUISA AGROPECUÁRIA. CENTRO NACIONAL DE PESQUISA DE SOLOS. Solos do Estado de Santa Catarina. Rio de Janeiro: EMBRAPA/CNPS, 2004. 1 CD-ROM.; mapa color. (Embrapa Solos. Boletim de Pesquisa e Desenvolvimento; n. 46).

FIGUEIREDO, C. C. et al. Propriedades físico-hídricas em Latossolo do Cerrado sob diferentes sistemas de manejo. Revista Brasileira de Engenharia Agrícola e Ambiental, v. 13, n. 2, p. 146-151, 2009.

FLORES, J. P. C. et al. Atributos físicos do solo e rendimento de soja em sistema plantio direto em integração lavoura- 
pecuária com diferentes pressões de pastejo. Revista Brasileira de Ciência do Solo, v. 31, n. 4, p. 771-780, 2007.

HAKANSSON, I.; VOORHEES, W. B. Soil compaction. In: LAL, R. et al. Methods for assessment of soil degradation. Boca Raton: CRC, 1998, p. 167-179.

LANZANOVA, M. E. et al. Atributos físicos do solo em sistema de integração lavoura-pecuária sob plantio direto. Revista Brasileira de Ciência do Solo, v. 31, n. 5, p. 11311140, 2007.

MARCHÃO, R. L. et al. Qualidade física de um Latossolo Vermelho sob sistemas de integração lavoura-pecuária no Cerrado. Revista Brasileira de Ciência do Solo, v. 42, n. 6, p. 873-882, 2007.

MIGUEL, F. R. et al. Variabilidade espacial da infiltração de água em solo sob pastagem em função da intensidade de pisoteio. Pesquisa Agropecuária Brasileira, v. 44, n. 11, p. 1513-1519, 2009.

NICOLOSO, R. S.; LANZANOVA, M. E.; LOVATO, T. Manejo de pastagens de inverno e potencial produtivo de sistemas de integração lavoura-pecuária no Estado do Rio Grande do Sul. Ciência Rural, v. 36, n. 6, p. 1799-1805, 2006.

PIMENTEL GOMES, F. Curso de estatística experimental. São Paulo: USP-Esalq, 1985. 468 p.

REICHER, J. M.; SUZUKI, L. E. A. S.; REINERT, D. J. Compactação do solo em sistemas agropecuários e florestais: identificação, efeitos, limites críticos e mitigação. Tópicos em Ciência do Solo, v.5, p.49-134, 2007.

SALTON, J. C. et al. Integrated crop-livestok system in tropical Brazil: toward a sustainable production system. Agriculture, Ecosystems and Environment, v. 185, n. 12, p. 1-10, 2013.
SILVA, V. R.; REINERT, D. J.; REICHERT, J. M. Densidade do solo, atributos químicos e sistema radicular do milho afetados pelo pastejo e manejo do solo. Revista Brasileira de Ciência do Solo, v. 24, n. 1, p. 191-199, 2000.

SPERA, S. T. et al. Efeitos de sistemas de produção de grãos envolvendo pastagens sob plantio direto nos atributos físicos de solo e na produtividade. Revista Brasileira de Ciência do Solo, v. 28, n. 3, p. 533-542, 2004.

TISDALL, J. M.; OADES, J. M. Organic matter and waterstable aggregates in soils. Journal of Soil Science, v. 33, n. 2, p. 141-163, 1982.

TREIN, C. R.; COGO, N. P.; LEVIEN, R. Métodos de preparo do solo na cultura do milho e ressemeadura do trevo na rotação aveia+trevo/milho, após pastejo intensivo. Revista Brasileira de Ciência do Solo, v. 15, n. 1, p. 105-111, 1991.

VEIGA, M. Metodologia para coleta de amostras e análises físicas do solo. Florianópolis: Epagri, 2011. 52 p. (Epagri. Boletim Técnico, 156).

VEIGA, M.; REINERT, D. J.; REICHERT, J. M. Aggregate stability as affected by short and long-term tillage systems and nutrient sources of a hapludox in southern Brazil. Revista Brasileira de Ciência do Solo, v. 33, n. 4, p. 767-777, 2009.

VEIGA, M. et al. Soil compressibility and penetrability of an Oxisol from southern Brazil, as affected by long-term tillage systems. Soil \& Tillage Research, v. 92, n. 1, p. 104-113, 2007.

VEIGA, M. et al. Short and long-term effects of tillage systems and nutrient sources on soil physical properties of a southern Brazilian Hapludox. Revista Brasileira de Ciência do Solo, v. 32, n.4, p. 1437-1446, 2008.

VEIGA, M. et al. Atributos de solo e de plantas afetados pelo manejo da pastagem anual de inverno em sistema de integração lavoura-pecuária. Ciência Rural, v. 42, n. 3, p. 444-450, 2012. 